\title{
Quality Indeks dan Konsentrasi Logam Berat dalam Perairan dan Sedimen di Perairan Kota Makassar
}

\author{
Funty Septiyawati Polapa ${ }^{1 *}$, Rahmawati Nur Annisa1, Dewi Yanuarita², Suharto M. Ali² \\ ${ }^{1}$ Program Studi Ilmu Kelautan, Universitas Muhammadiyah Palopo; \\ 2Program Studi Managemen Sumberdaya Perairan, Universitas Hasanuddin
}

\begin{abstract}
ABSTRAK
Kota Makassar merupakan pusat kota di Provinsi Sulawesi Selatan yang memiliki aktifitas wilayah pesisir, seperti pemanfataan industri, pariwisata, transportasi laut serta memiliki dua sungai besar yang muara di perairan. Penelitian ini bertujuan untuk mengetahui konsentrasilogam berat dalam air dan sedimen serta menentukan status mutunya. Pengamatan dilakukan pada 10 lokasi strategis sumber pencemar seperti pabrik, hotel, muara sungai serta pelabuhan dengan mengambil sampel air dan sedimen dan selanjutnya dianalisis di laboratorium untuk logam berat $\mathrm{Cd}, \mathrm{Cr}, \mathrm{Hg}$, Zn, $\mathrm{Cu}$ dan Pb. Statistik deskriptif digunakan untuk menganalisis data yang ada. Metode Indeks Pencemar dan Storet (Storage and Retrieval) digunakan untuk menentukan status mutu air dan sedimen dari logam berat untuk biota laut. Hasil penelitian ini menunjukkan perairan Kota Makassar tergolong dalam kategori "Cemar Ringan" berdasarkan hasil perhitungan indeks Pencemar sedangkan status mutu perairan tergolong "Cemar Berat". Parameter logam berat di kolom perairan yang melampaui baku mutu adalah Krom $(0,016 \pm 0,005)$ dan Tembaga $(0,112 \pm 0,035)$. Sedangkan untuk parameter logam berat sedimen secara keseluruhan masih berada dalam ambang batas baku mutu yang telah ditentukan. Kondisi tercemar berasal dari aktifitas reklamasi pantai serta sumber alami dan limbah domestik dari aktifitas masyarakat cukup tinggi.
\end{abstract}

Kata kunci: Logam Berat, Perairan Laut, Sedimen Laut, Kota Makassar

\begin{abstract}
Makassar City is the city center in South Sulawesi Province which has coastal area activities, such as the use of industry, tourism, sea transportation and has two large rivers that estuary into the waters. This study aims to determine the concentration of heavy metals in water and sediment and determine their quality status. Observations were made at 10 strategic locations of pollutant sources such as factories, hotels, river mouths, and ports by taking water and sediment samples and then analyzed in the laboratory for heavy metals $\mathrm{Cd}, \mathrm{Cr}, \mathrm{Hg}, \mathrm{Zn}, \mathrm{Cu}$, and $\mathrm{Pb}$. Descriptive statistics are used to analyze the existing data. The Pollutant Index and Storet (Storage and Retrieval) method is used to determine the status of water and sediment quality of heavy metals for marine biota. The results of this study indicate that the waters of Makassar City are classified as "Lightly Polluted" based on the results of the calculation of the Pollutant index while the status of the water quality is classified as "Heavy Polluted". Parameters of heavy metals in the water column that exceed the quality standard are chromium $(0,016 \pm 0,005)$ and copper $(0,112 \pm 0,035)$. Meanwhile, the parameters of the sediment heavy metals as a whole are still within the specified quality standard. Polluted conditions derived from coastal reclamation activities as well as natural sources and domestic waste from community activities are quite high.
\end{abstract}

Keywords: Heavy Metal, Marine Water, Marine Sediment, Quality Indeks

Sitasi: Polapa, F.S., Annisa, R.N., Yanuarita, D., Ali, S.M. (2022). Quality Indeks dan Konsentrasi Logam Berat dalam Perairan dan Sedimen di Perairan Kota Makassar. Jurnal Ilmu Lingkungan, 20(2), 271-278, https://doi.org/10.14710/jil.20.2.271-278

\section{Latar Belakang}

Logam berat disebut sebagai polutan umum yang dapat ditemukan pada berbagai media lingkungan. Efek yang diberikan dapat dengan mudah terakumulasi kedalam tubuh organisme dan berdampak pada keberlangsungan hidup. Dampak tersebut dapat berakhir pada tubuh manusia setelah konsentrasi dan pembesaran melalui rantai makanan. Sumber logam berat berasal dari sumber alami dan kegiatan antropogenik. Secara alami logam berat dihasilkan dari deposisi atmosfer langsung, pelapukan geologis, sedangkan dari kegiatan antropologi dihasilkan dari produk limbah pertanian, kota, perumahan serta industry (Han et al., 2016)(Yi et al., 2011). Migrasi dan transformasi logam berat dapat menggunakan air, sedimen dan zoobenthos sebagai media pembawa dan penyimpanan.

Karakteristik distribusi logam berat di berbagai media lingkungan dapat mencerminkan tingkat polusi dan potensi efeknya terhadap kesehatan ekosistem

\footnotetext{
*Penulis korespondensi: Funtyseptiyawati@umpalopo.ac.id
} 
perairan (Fang et al., 2017). Penyerapan logam berat dalam sedimen perairan dapat memainkan peran kunci dalam mengatur migrasi, transformasi dan pemurnian logam berat dalam ekosistem perairan (Banerjee et al., 2016). Logam berat yang telah terkena air akan diserap dan akhirnya diendapkan oleh partikel seperti sedimen dan akan terakumulasi sebagai endapan. Selanjutnya, biota seperti zoobenthos dapat mengambil jejak logam dari sedimen dan partikulat tersuspensi melalui penggembalaan dan transformasi sel (Zhang et al., 2015). Biokonsentrasi logam berat dari sedimen dan masuknya zat beracun ke dalam rantai makanan dan meracuni organisme air dan selanjutnya merusak kesehatan organisme darat dan manusia (Angelidis \& Aloupi, 2000). Misalnya, bivalvia limnofag menimbun logam berat melalui asupan partikel tersuspensi atau partikel sedimen permukaan di dasar sungai (Li et al., 2019). Oleh karena itu, mengidentifikasi karakteristik distribusi dan tingkat pencemaran logam berat di media lingkungan yang berbeda akan membantu untuk menjelaskan tingkat akumulasi mereka dan risiko lingkungan yang sesuai.

Kota Makassar merupakan pusat kota yang terletak di Provinsi Sulawesi Selatan. Hal tersebut menyebabkan peningkatan jumlah penduduk dan aktifitas wilayah pesisir, seperti pemanfataan industri, pariwisata dan transportasi laut. Terdapat dua sungai besar yang bermuara di perairan yaitu Sungai Tallo dan
Sungai Jeneberang. Juga terdapat sebelas saluran drainase yang berasal dari pemukiman masyarakat.

Informasi awal tentang potensi logam berat sebagai pencemar di kawasan pesisir Kota Makassar perlu diketahui. Hal penting yang dilakukan adalah menentukan sumber logam berat dan mengelolanya sehingga konsentrasi logam tersebut ketika masuk ke dalam air dan sedimen tidak bersifat beracun. Penelitian ini bertujuan untuk mengetahui konsentrasi beberapa logam berat dalam air dan sedimen serta menentukan status mutunya, terkait dengan potensi pencemaran di Kota Makassar, Provinsi Sulawesi Selatan.

\section{Metodologi}

\subsection{Lokasi dan Waktu}

Pengambilan sampel dilakukan sebanyak empat kali berturut-turut yakni tiap bulan agustus tahun 2018 hingga 2021. Sampel yang akan di analisis yakni air laut yang ambil pada 10 titik dan sampel sedimen 3 titik di sepanjang pesisir Kota Makassar (Gambar 1). Penentuan titik pengambilan sampel ini mengikuti lokasi bangunan atau kawasan yang dapat menjadi sumber bahan pencemar (Tabel 1).

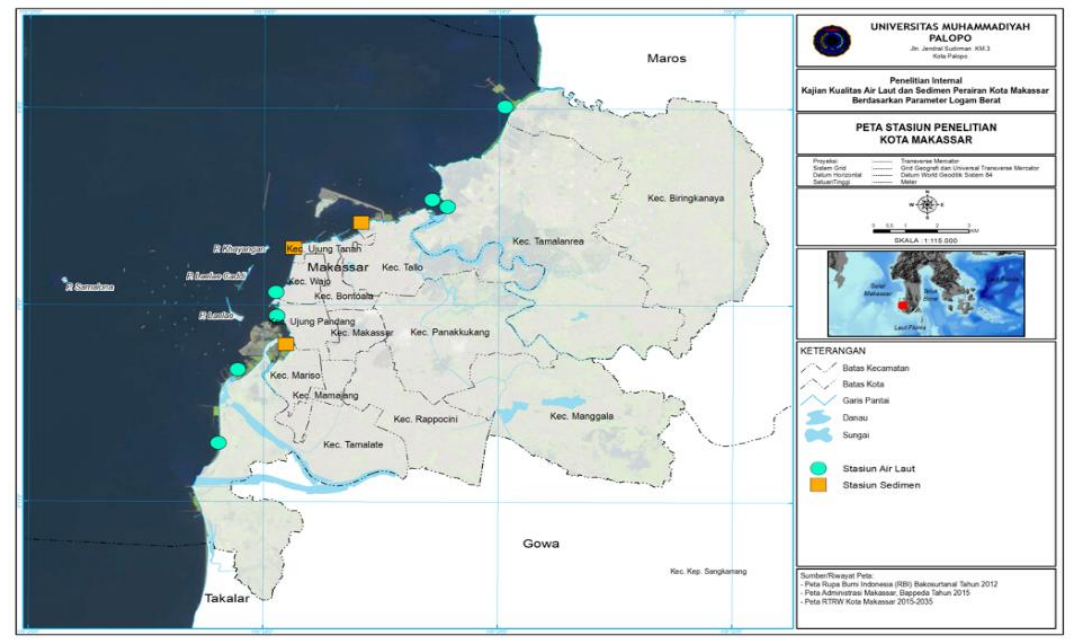

Gambar 1 Lokasi Penelitian

Tabel 1 Deskripsi lokasi penelitian

\begin{tabular}{ccccl}
\hline \multirow{2}{*}{ Stasiun } & \multirow{2}{*}{ Lokasi } & \multicolumn{2}{c}{ Koordinat } & \multicolumn{1}{c}{ Deskripsi Lokasi } \\
\cline { 2 - 4 } & & X & Y & \\
\hline 1 & TB & 119,387097 & $-5,180169$ & Destinasi wisata pantai \\
2 & TM & 119,392527 & $-5,155247$ & Belakang bangunan mall \\
3 & CPI & 119,406225 & $-5,14666$ & Kegiatan reklamasi pantai \\
4 & MGH & 119,403609 & $-5,137042$ & Hotel \\
5 & PU & 119,468218 & $-5,066064$ & Kegiatan Pelabuhan \\
6 & PK & 119,451893 & $-5,099958$ & Pusat perindustrian \\
7 & MST & 119,447597 & $-5,097639$ & Muara Sungai \\
8 & PI & 119,427466 & $-5,105341$ & Industri Kapal \\
9 & PE & 119,408267 & $-5,113999$ & Pabrik Tepung \\
10 & PS & 119,403267 & $-5,129036$ & Kegiatan Pelabuhan \\
\hline
\end{tabular}




\subsection{Pengumpulan Data Lapangan}

Pengambilan sampel air laut dilakukan dengan menggunakan Niskin Water Sample dengan kapasistas 2,2 L. Penggunaan alat ini dapat memudahkan peneliti untuk mengambil air laut pada kedalaman tertentu. Sampel air laut diambil sebanyak 2L yang disimpan pada botol Polietilena. Pengambilan sampel sedimen dilakukan menggunakan Van Veen Grab yang terbuat dari stainless steel yang di simpan dalam wadah Polietilena. Saat proses pengambilan, sampel diletakkan dalam kotak pendingin kemudian dibawah ke laboratorium dan disimpan didalam pendingin $\left(4^{\circ} \mathrm{C}\right)$. Analisis sampel dilakukan di laboratorium Kesehatan Kota Makassar yang telah terakreditasi nasional. Paremeter logam berat yang akan dianalisis adalah $\mathrm{Cu}, \mathrm{Pb}, \mathrm{Zn}, \mathrm{Cd}, \mathrm{Hg}$ dan $\mathrm{Cr}$ IV sesuai dengan pernyataan (Huang et al., 2007) bahwa limbah buangan industri dapat berupa $\mathrm{Cu}, \mathrm{Pb}, \mathrm{Zn}$ dan $\mathrm{Cd}$ yang dapat terakumulasi dilingkungan perairan.

\subsection{Analisis Sampel}

Prosedur analisis logam berat pada sampel air mengikuti petunjuk metode standar untuk pemeriksaan air dan air limbah (APHA-AWWA-WEF, 2012). Metode yang digunakan yaitu Atomicabsorption spectrometry (AAS) dengan menggunakan prinsip penyerapan energi (radiasi pada panjang gelombang tertentu) oleh atom sehingga menimbulkan keadaan energi elektronik tereksitasi.

\subsection{Analisis Data}

Hasil pengukuran logam berat dianalisis menggunakan aplikasi SPSS dengan Uji One Way Anova untuk melihat perbedaan data tiap tahun pengamatan. Standar baku mutu yang digunakan berdasarkan Peraturan Pemerintah Indonesia nomor 22 Tahun 2021 pada lampiran VII (PP RI No 22, 2021). Nilai baku mutu yang digunakan berdasarkan peruntukan air laut baik itu untuk Biota, Wisata dan Pelabuhan. Status mutu air dihitung menggunakan metode STORET berdasarkan (Keputusan Menteri Negara Lingkungan Hidup, 2003). Prinsipnya membandingkan antara data kualitas air dengan baku mutu air yang disesuaikan dengan peruntukannya guna menentukan status mutu air. Adapun status mutu air diklasifikasikan dalam empat kelas, yaitu: (1) kelas A: baik sekali, skor = 0: memenuhi baku mutu; (2) kelas B: baik, skor = -1 sampai dengan 10: tercemar ringan; (3) kelas C: sedang, skor $=-11$ sampai dengan - 30: tercemar sedang; dan (4) kelas D: buruk, skor < -31: tercemar berat. Selain itu juga dilakukan perhitungan Indeks Pencemar (IP) yang diacu dari Sumitomo dan Nemerow (1970) dalam (Keputusan Menteri Negara Lingkungan Hidup, 2003). Perhitungan IP diperlukan untuk mengetahui kualitas badan air untuk suatu peruntukan. Evaluasi terhadap nilai IP sebagai berikut $<0 \mathrm{~s} / \mathrm{d}$ 1,0: memenuhi baku mutu (kondisi baik); 1,0 s/d 5,0: cemar ringan; 5,0 s/d 10: cemar sedang; > 10: cemar berat.

\section{Hasil dan Pembahasan}

\subsection{Logam Berat di Kolom Perairan}

Pencemaran logam berat di lingkungan laut telah menjadi isu yang menjadi perhatian utama, karena sebagian besar logam berat tersebut terangkut ke lingkungan laut dan terakumulasi tanpa mengalami dekomposisi (Halttunen et al., 2007). Salah satu cara mengetahui pencemaran logam berat di lingkungan laut ditentukan dengan mengukur konsentrasi dalam air dan sedimen (R. Li et al., 2020). Kandungan logam berat pada peraitan Kota Makassar ditemukan sangat berfluktuatif (Tabel 2).

Berdasarkan hasil pengukuran didapatkan 6 kandungan logam berat di perairan Kota Makassar yakni $\mathrm{Cd}, \mathrm{Cr}, \mathrm{Hg}$, $\mathrm{Zn}, \mathrm{Cu}$ dan $\mathrm{Pb}$. Kandungan Cadmium (Cd) pada perairan Kota Makassar ditemukan sama selama 4 tahun pengamatan yakni $0,001 \pm 2,28 \mathrm{mg} / \mathrm{l}$. Cd merupakan salah satu komponen logam berat yang sangat beracun terlebih ketika penyerapannya melalui air (Halttunen et al., 2007). Kandungan Cd di perairan dapat berasal dari limbah rumah tangga serta aktifitas perbaikan atau pembuatan kapal (Rumahlatu, 2012). Menurut PP RI No 22 tahun 2021 tentang tentang baku mutu air laut untuk biota kandungan Cd diperairan Kota Makassar masih berada dalam ambang batas yang telah ditetapkan yakni maksimal 0,001 mg/l.

Tabel 2 Logam berat pada kolom perairan Kota Makassar

\begin{tabular}{|c|c|c|c|c|c|}
\hline \multirow{2}{*}{$\begin{array}{c}\text { Logam } \\
\text { Berat }\end{array}$} & \multicolumn{4}{|c|}{ Range (mean \pm Stdv) } & \multirow[t]{2}{*}{$\begin{array}{l}\text { Quality Standar } \\
(\mathrm{mg} / \mathrm{l})\end{array}$} \\
\hline & 2018 & 2019 & 2020 & 2021 & \\
\hline $\mathrm{Cd}(\mathrm{ppm})$ & $0,001 \pm 0$ & $0,001 \pm 0$ & $0,001 \pm 0$ & $0,001 \pm 0$ & $0,001^{*}$ \\
\hline $\mathrm{Cr}(\mathrm{ppm})$ & $0,01 \pm 0$ & $0,01 \pm 0$ & $0,016 \pm 0,005$ & $0,01 \pm 0$ & $0,005^{*}$ \\
\hline $\mathrm{Hg}(\mathrm{ppm})$ & $0,0005 \pm 0$ & $0,005 \pm 0$ & $0,0005 \pm 0$ & $0,0005 \pm 0$ & $0,001^{*}$ \\
\hline $\mathrm{Zn}(\mathrm{ppm})$ & $0,012 \pm 0,01$ & $0,01 \pm 0$ & $0,01 \pm 0$ & $0,01 \pm 0$ & $0,05^{*}$ \\
\hline $\mathrm{Cu}(\mathrm{ppm})$ & $0,0055 \pm 0,001$ & $0,006 \pm 0,005$ & $0,007 \pm 0,002$ & $0,112 \pm 0,035$ & $0,008^{*}$ \\
\hline $\mathrm{Pb}(\mathrm{ppm})$ & $0,005 \pm 0$ & $0,004 \pm 0,001$ & $0,005 \pm 0$ & $0,005 \pm 0$ & $0,008^{*}$ \\
\hline
\end{tabular}

Note : *(PP RI No 22, 2021) Lampiran VIII peruntukan Biota Laut 
Krom (Cr) yang diamati adalah jenis Cr IV. Berdasarkan hasil pengamatan ditemukan kandungan $\mathrm{Cr}$ perairan mengalami peningkatan pada tahun 2020 yakni sebesar $0,016 \pm 0,005 \mathrm{mg} / \mathrm{l}$. sedangkan pada tahun sebelumnya ditemukan kandungan $\mathrm{Cr}$ sebesar $0,01 \pm 1,82 \mathrm{mg} / \mathrm{l}$, nilai yang sama pada pengamatan tahun 2021. Logam $\mathrm{Cr}$ tergolong logam yang hadir di alam akibat aktivitas alami seperti kegiatan vulkanik dan aktivitas buatan (antropogenik) seperti kegiatan pertaniaan dalam pemakaian pupuk dan pestisida (Desvars et al., 2011). Berdasarkan baku mutu yang telah ditentukan rata-rata kandungan $\mathrm{Cr}$ di perairan Makassar telah melampaui baku mutu pada seluruh waktu pengamatan kecuali pada tahun 2019. Sama halnya dengan $\mathrm{Cd}$, kandungan Raksa (Hg) diperairan Kota Makassar ditemukan sama sebesar $0,0005 \pm 1,14$ $\mathrm{mg} / \mathrm{l}$. Hg masuk dalam perairan melalui dekomposisi atmosfer atau bersumber dari eksternalisasi limbah industri dan diubah secara biologis dan kimiawi menjadi metil merkuri (Yusuf \& Hamzah, 2013). Kandungan Hg diperairan Kota Makassar masih berada dalam ambang baku mutu yang telah ditetapkan yakni sebesar 0,001 mg/l.

Kandungan Seng (Zn) yang ditemukan di Perairan Kota Makassar relatif seragam yakni 0,01 $\pm 1,82 \mathrm{mg} / \mathrm{l}$, kecuali pada pengamatan tahun 2018 ditemukan kandungan seng perairan lebih besar dengan nilai 0,012 $\pm 0,01 \mathrm{mg} / \mathrm{l}$. Rata-rata kandungan $\mathrm{Zn}$ yang ditemukan di perairan Kota Makassar masih berada dalam ambang baku mutu yang telah ditetapkan. Kandungan Zn diperairan berasal dari aktifitas rumah tangga, pertanian yang menggunakan pupuk dan pestisida, aktifitas industry dan limbah domestik (Mustafa et al., 2021). Kandungan tembaga (Cu) yang ditemukan pada perairan Kota Makassar terlihat tinggi pada pengamatan tahun 2021. Jika tahun sebelumnya kandungan $\mathrm{Cu}$ yang didapatkan berkisar antara $0,0055 \pm 0,001 \mathrm{mg} / \mathrm{l}$ hingga $0,112 \pm 0,035 \mathrm{mg} / \mathrm{l}$, pada tahun 2021 kandungan Cu Perairan Kota Makassar mencapai nilai tertinggi. kandungan $\mathrm{Cu}$ diperairan dapat berasal dari kegiatan pertanian (Azhar et al.,
2012), buangan industri, galangan kapal, dan pengolahan industri $\mathrm{Cu}$ (Rompas, 2010). Kandungan $\mathrm{Cu}$ diperairan Kota Makassar telah melampau baku mutu yang telah ditentukan dengan nilai standar sebesar 0,008 mg/l. Kandungan Timbal $(\mathrm{Pb})$ yang ditemukan pada Perairan Kota Makassar memiliki nilai yang relatif sama yakni $0,005 \pm 9,14 \mathrm{mg} / \mathrm{l}$. kecuali pada tahun 2019 ditemukan kandungan $\mathrm{Pb}$ sebesar $0,004 \pm 0,001 \mathrm{mg} / \mathrm{l}$. kandungan $\mathrm{Pb}$ diperairan dapat berasal dari aktivitas rumah tangga serta tumpahan minyak kapal yang melintas (Mustafa et al., 2021). Menurut standar baku mutu yang ditetapkan kiandungan timbal diperairan Kota Makassar masih berada dalam ambang batas baku mutu.

Kandungan logam berat pada kolom perairan kota Makassar secara keseluruhan masih berada dalam ambang batas baku mutu menurut PP RI No 22 Tahun 2021 pada lampiran VIII, kecuali parameter logam $\mathrm{Cr}$ dan $\mathrm{Cu}$. Rendahnya kadar logam berat dikolom air karena sifatnya yang mudah larut dan berubah dari bentuk karbonat menjadi hidrosida membentuk suatu ikatan pertikel, kemudian mengendap pada dasar perairan (sedimen) (Rachmawatie et al., 2009). Kondisi ini merupakan input kontaminan logam berat masih cenderung dari darat (Arifin et al., 2010)

\subsection{Logam Berat dalam Sedimen}

Berdasarkan hasil pengamatan kandungan logam berat pada sedimen terlihat lebih tinggi dan beragam di Perairan Kota Makassar. Menurut (Priyanto et al., 2008) logam berat yang ada pada kolom air akan larut, tetapi jika tidak larut di kolom air, selanjutnya akan terendapkan di dasar perairan (sedimen) sehingga kadar logam berat yang terkandung pada sedimen akan lebih tinggi dibandingkan kandungan logam berat yang ada di kolom air. Sedimen yang terkontaminasi logam berat dengan kadar yang tinggi akan mempengaruhi kehidupan ekosistem perairan (Malik \& Maurya, 2015).

Tabel 3 Logam berat pada sedimen perairan Kota Makassar

\begin{tabular}{|c|c|c|c|c|c|}
\hline \multirow{2}{*}{$\begin{array}{l}\text { Heavy } \\
\text { Metal }\end{array}$} & \multicolumn{4}{|c|}{ Range (mean \pm Stdv) } & \multirow[t]{2}{*}{$\begin{array}{c}\text { Quality } \\
\text { Standar (ppm) }\end{array}$} \\
\hline & 2018 & 2019 & 2020 & 2021 & \\
\hline $\mathrm{Cd}(\mathrm{ppm})$ & $0,05 \pm 0,07$ & $0,27 \pm 0,14$ & $0,39 \pm 0,23$ & $0,09 \pm 0,02$ & $5,1^{*}$ \\
\hline $\mathrm{Cr}(\mathrm{ppm})$ & $0,34 \pm 0,33$ & $0,01 \pm 0$ & $26,65 \pm 5,81$ & $19,13 \pm 1,80$ & $260^{*}$ \\
\hline $\mathrm{Hg}(\mathrm{ppm})$ & $0,32 \pm 0,04$ & $0,01 \pm 0,01$ & $0,001 \pm 0$ & $0,08 \pm 0,02$ & $0,41^{*}$ \\
\hline $\mathrm{Zn}(\mathrm{ppm})$ & $177 \pm 94,95$ & $22,51 \pm 2,68$ & $52,63 \pm 10,64$ & $31,39 \pm 13,06$ & $410^{*}$ \\
\hline $\mathrm{Cu}(\mathrm{ppm})$ & $48,54 \pm 5,02$ & $15,41 \pm 6,1$ & $24,73 \pm 7,01$ & $9,28 \pm 3,93$ & $390^{*}$ \\
\hline $\mathrm{Pb}(\mathrm{ppm})$ & $37,63 \pm 5,1$ & $9,1 \pm 3,76$ & $11,49 \pm 1,96$ & $11,71 \pm 2,33$ & $450^{*}$ \\
\hline
\end{tabular}

Note : * (Department of Ecology State of Washington, 2013) untuk sedimen laut 
Kandungan logam berat $\mathrm{Cd}$ pada sedimen ditemukan

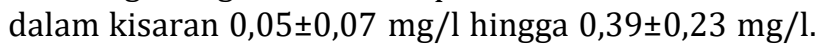
Berdasarkan hasil pengamatan selama 4 tahun terakhir, Cd ditemukan paling besar pada tahun 2020 . penyebabnya diduga akibat aktifitas raklamasi pantai yang sangat aktif pada tahun 2020. Hal ini didukung oleh pernyataan (Alisa et al., 2020) bahwa Kandungan Cd diperairan dapat berasal dari aktvitas reklamasi Pantai. Logam berat $\mathrm{Cr}$ yang ditemukan pada sedimen

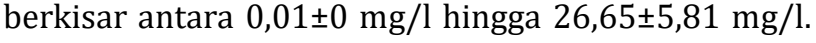
Hasil Pengamatan terakhir menunjukkan peningkatan kandungan logam berat Cr di Perairan Kota Makassar selama 2 tahun terakhir yakni 2020 dan 2021. Namun nilai tersebut masih berada dalam ambang batas baku mutu yang telah ditetapkan. Berbeda dengan $\mathrm{Cr}$, kandungan logam berat $\mathrm{Hg}$ ditemukan paling tinggi pada tahun 2018, namun mengalami penurunan pada tahun 2019 dan 2020. Kemudian ditemukan meningkat lagi pada tahun 2021 meskipun kadarnya tidak sebesar tahun 2018. Kadar Hg diperairan Kota Makassar berkisar antara $0,001 \pm 0 \mathrm{mg} / \mathrm{l}$ hingga $0,32 \pm 0,04 \mathrm{mg} / \mathrm{l}$. Nilai ini masih berada dalam ambang batas baku mutu yang telah ditetapkan untuk sedimen yakni maksimal 0,41mg/l. Sama halnya dengan Hg, Kandungan Zn pada sedimen ditemukan tinggi pada tahun 2018, namun mengalami penurunan pada tahun berikutnya. Kandungan $\mathrm{Zn}$ pada sedimen berkisar antara $22,51 \pm 2,68 \mathrm{mg} / \mathrm{l}$ hingga $177 \pm 94,95 \mathrm{mg} / \mathrm{l}$. Nilai ini tergolong rendah mengingat standar baku mutu sedimen untuk Zn maksimal $410 \mathrm{mg} / \mathrm{l}$. Dalam konsentrasi rendah $\mathrm{Zn}$ dibutuhkan oleh organisme akuatik sebagai koenzim, namun dalam berubah menjadi racun jika ditemukan dalam kadar yang tinggi (Draszawka \& Cyraniak, 2014). Trend kandungan $\mathrm{Cu}$ dalam sedimen sama dengan $\mathrm{Hg}$. Ditemukan tinggi pada tahun 2018 dan naik turun pada tahun berikutnya. Kandungan $\mathrm{Cu}$ dalam sedimen berkisar

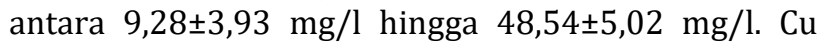
dalam konsentrasi tinggi dapat bersifat racun, namun dalam konsentrasi rendah diperlukan oleh organisme sebagai koenzim dalam proses metabolism tubuh (Draszawka \& Cyraniak, 2014). Kandungan Pb dalam sedimen ditemukan ralatif sama kecuali pada tahun 2019 yang berkisar antara 9,1 $\pm 3,76 \mathrm{mg} / \mathrm{l}$ hingga $37,63 \pm 5,1 \mathrm{mg} / \mathrm{l}$. Kandungan $\mathrm{Pb}$ pada sedimen perairan Kota Makassar masih berada dalam ambang batas baku mutu yang telah ditentukan. Kadar Pb diperairan dapat berasal dari umber $\mathrm{Pb}$ juga berasal dari berbagai faktor, seperti aktivitas manusia yakni aktivitas perbengkelan, pembuangan timbal, adapun sumber dari alam seperti pengikisan batuan mineral dan pemakaian bahan bakar timbal (Ika et al., 2012).

\subsection{Indeks Pencemaran}

Kondisi perairan Kota Makassar ditentukan berdasarkan metode indeks Pencemar (IP). Paramater yang digunakan dalam perhitungan ini adalah logam berat $\mathrm{Cd}, \mathrm{Cr}, \mathrm{Hg}$, $\mathrm{Zn}, \mathrm{Cu}$ dan $\mathrm{Pb}$ berdasarkan baku mutu (PP RI No 22, 2021) peruntukan biota laut dan (Department of Ecology State of Washington, 2013) peruntukan sedimen laut. Berdasarkan hasil pengamatan kondisi perairan Kota Makassar mengalami peningkatan pencemaran dalam 4 tahun terakhir. Namun nilai tersebut masih berada dalam "Kondisi Baik" pada kolom perairan dan Sedimen. Terkecuali pada IP kolom perairan tahun 2021 yang telah masuk pada kelas "Cemar Ringan".

\subsection{Status Mutu Perairan}

Penentuan status mutu perairan Kota Makassar menggunakan metode storet. Hal serupa telah dilakukan dibeberapa perairan diantaranya Wakatobi (Asuhadi, 2018); Batam (Sachoemar., dkk, 2018); Jayapura (Walukow, 2010); Gorontalo (Kadim et al., 2017). Hasil pengukuran menunjukkan kondisi kolom perairan Kota Makassar masuk dalam kategori "Cemar Berat" serta terjadi peningkatan pencematan pada tahun 2021.

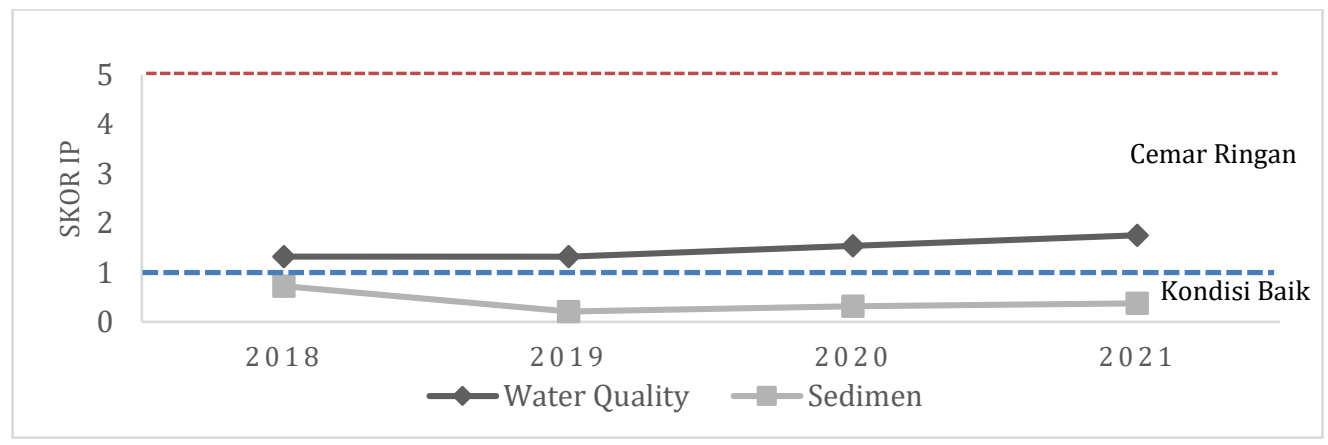

Gambar 2 Skor Indeks Pencemar (IP) Kota Makassar berdasarakan Parameter Logam berat (<0 s/d 1,0: kondisi baik; 1,0 s/d 5,0: cemar ringan; 5,0 s/d 10: cemar sedang; > 10: cemar berat). 


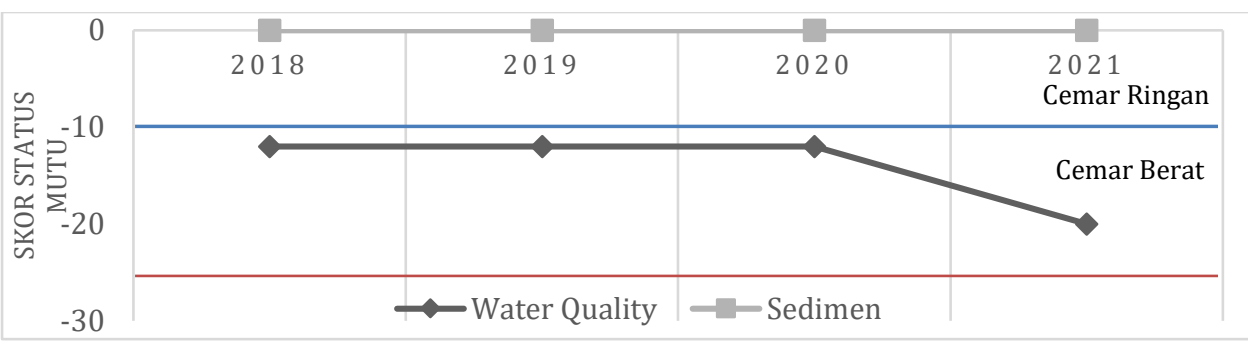

Gambar 3 Skor Status Mutu Perairan Kota Makassar Berdasarkan metode STORET menggunakan parameter logam berat ((1) kelas A: baik sekali, skor = 0: memenuhi baku mutu; (2) kelas B: baik, skor = -1 sampai dengan -10: tercemar ringan; (3) kelas C: sedang, skor = -11 sampai dengan - 30: tercemar sedang; dan (4) kelas D: buruk, skor < -31: tercemar berat.)

\subsection{Sumber polusi logam berat}

Wilayah pesisir Kota Makassar berkembang pesat yang ditandai dengan reklamasi laut untuk pemukiman, pusat perniagaan, industri dan pelabuhan. Aktivitas tersebut dapat menimbulkan penurunan kualitas perairan pesisir Kota Makassar (Setiawan, 2013). Konsentrasi logam berat seperti $\mathrm{Cu}, \mathrm{Zn}, \mathrm{Cd}$ dan $\mathrm{Hg}$ terdistribusi dilingkungan alam (Voica et al., 2017) dan lingkungan perairan (Huang et al., 2007). Logam yang memasuki kolom air kemudian terakumulasi kedalam sedimen yang berasal dari aktivitas manusia seperti pertambangan, peleburan logam dan pembuangan dan pembuangan air limbah industri, penggunaan bahan bakar fosil, buangan pestisida/pupuk pertanian dan limbah rumah tangga (Han et al., 2016)(Yi et al., 2011). Reklamasi bisa memberikan dampak buruk pada lingkungan karena terjadi proses reaksi kimia antara pore water dan sedimen dikawasan reklamasi(Suryono, 2016). Menurut (Amin et al., 2011) sebanyak $90 \%$ logam berat terdapat di lingkungan perairan akan berupa endapan dalam sedimen. Selain dari itu, (Fredy Leiwakabessy, 2005) mengatakan bahwa logam berat mempunyai sifat yang mengikat bahan organik dan mengendap didasar perairan dan bersatu dalam sedimen sehingga kadar logam berat akan menjadi lebih tinggi dibandingan kadar logam berat dalam air. Upaya yang dapat dilakukan pemerintah dalam pengurangan indeks pencemar khususnya logam berat pada Perairan Kota Makassar adalah dengan peningkatan konservasi ekosistem laut seperti Penanaman Mangrove. Vegetasi mangrove mempunyai mekanisme untuk menghadapi konsentrasi polutan yang tinggi dengan cara ameliorasi dan toleransi (Setiawan, 2013).

\section{Kesimpulan}

Kondisi perairan Kota Makassar berdasarkan hasil perhitungan indeks Pencemar tergolong dalam kategori "Cemar Ringan" dan berdasarkan status mutu perairan masuk dalam ketegori "Cemar Berat". Parameter logam berat di kolom perairan yang melampaui baku mutu adalah Krom dan Tembaga. Sedangkan untuk parameter logam berat sedimen secara keseluruhan masih berada dalam ambang batas baku mutu yang telah ditentukan. Kondisi tercemar berasal dari aktifitas reklamasi pantai serta sumber alami dan limbah domestik dari aktifitas masyarakat cukup tinggi.

\section{DAFTAR PUSTAKA}

Alisa, C. A. G., Albirqi P, M. S., \& Faizal, I. (2020). Kandungan Timbal dan Kadmium pada Air dan Sedimen di Perairan Pulau Untung Jawa, Jakarta. Akuatika Indonesia, 5(1), 21. https://doi.org/10.24198/jaki.v5i1.26523

Amin, B., Afriyani, E., \& Saputra, M. A. (2011). Distribusi Spasial Logam $\mathrm{Pb}$ dan $\mathrm{Cu}$ pada Sedimen dan Air Laut Permukaan di Perairan Tanjung Buton Kabupaten Siak Provinsi Riau. Jurnal Teknobiologi, II (1), 1-8.

Angelidis, M. O., \& Aloupi, M. (2000). Geochemical study of coastal sediments influenced by rivertransported pollution: Southern Evoikos Gulf, Greece. Marine Pollution Bulletin, 40(1), 77-82. https://doi.org/10.1016/S0025326X(99)00174-5

Arifin, Z., Pertanian, I., Kampus, B., \& Dramaga, I. P. B. (2010). Fraksinasi Logam Berat Pb, Cd, Cu dan Zn dalam Sedimen dan Bioavailabilitasnya bagi Biota di Perairan Teluk Jakarta. ILMU KELAUTAN: Indonesian Journal of Marine Sciences, 14(1), 2732. https://doi.org/10.14710/ik.ijms.14.1.27-32

Asuhadi, S. (2018). Status Mutu Air Pelabuhan Panggulubelo Berdasarkan Indeks Storet Dan Indeks Pencemaran. Jurnal Kelautan Nasional, 13(2). https://doi.org/10.15578/jkn.v13i2.6475

Azhar, H., Widowati, I., Suprijanto, J., Tembalang, K., Fax, S. T., Batang, K., Pekalongan, K., \& Brebes, K. (2012). Studi Kandungan Logam Berat $\mathrm{Pb}, \mathrm{Cu}, \mathrm{Cd}$, $\mathrm{Cr}$ Pada Kerang Simping (Amusium pleuronectes), Air Dan Sedimen Di Perairan Wedung, Demak Serta Analisis Maximum Tolerable Intake Pada Manusia. Diponegoro Journal of Marine Research, 1(2), 35-44. https://doi.org/10.14710/jmr.v1i2.2017

Banerjee, S., Kumar, A., Maiti, S. K., \& Chowdhury, A. (2016). Seasonal variation in heavy metal 
Polapa, F.S., Annisa, R.N., Yanuarita, D., Ali, S.M. (2022). Quality Indeks dan Konsentrasi Logam Berat dalam Perairan dan Sedimen di Perairan Kota Makassar. Jurnal IImu Lingkungan, 20(2), 271-278, https://doi.org/10.14710/jil.20.2.271-278

contaminations in water and sediments of Jamshedpur stretch of Subarnarekha river, India. Environmental Earth Sciences, 75(3), 1-12. https://doi.org/10.1007/s12665-015-4990-6

Department of Ecology State of Washington. (2013). Sediment Management Standards. In Sediment Management Standards (Issue 13). https://www.epa.gov/sites/production/files/20 14-12/documents/wa-chapter173-204.pdf

Desvars, A., Jégo, S., Chiroleu, F., Bourhy, P., Cardinale, E., \& Michault, A. (2011). Seasonality of human leptospirosis in Reunion Island (Indian Ocean) and its association with meteorological data. PLoS ONE, 6(5). https://doi.org/10.1371/journal.pone.0020377

Draszawka, B., \& Cyraniak, E. (2014). Heavy metals in circulation biogeochemical. World Scientific News, 3, 26-34.

Fang, T., Lu, W., Li, J., Zhao, X., \& Yang, K. (2017). Levels and risk assessment of metals in sediment and fish from Chaohu Lake, Anhui Province, China. Environmental Science and Pollution Research, 24(18), 15390-15400. https://doi.org/10.1007/s11356-017-9053-y

Fredy Leiwakabessy. (2005). ADLN - Perpustakaan Universitas Airlangga Disertasi Logam Berat di Perairan Pantai Pulau Ambon ...

Halttunen, T., Salminen, S., \& Tahvonen, R. (2007). Rapid removal of lead and cadmium from water by specific lactic acid bacteria. International Journal of Food Microbiology, 114(1), 30-35. https://doi.org/10.1016/j.ijfoodmicro.2006.10.0 40

Han, D., Currell, M. J., \& Cao, G. (2016). Deep challenges for China's war on water pollution. Environmental Pollution, 218, 1222-1233. https://doi.org/10.1016/j.envpol.2016.08.078

Huang, S. S., Liao, Q. L., Hua, M., Wu, X. M., Bi, K. S., Yan, C. Y., Chen, B., \& Zhang, X. Y. (2007). Survey of heavy metal pollution and assessment of agricultural soil in Yangzhong district, Jiangsu Province, China. Chemosphere, 67(11), 21482155.

https://doi.org/10.1016/j.chemosphere.2006.12 .043

Ika, Tahril, \& Said, I. (2012). Analisis Logam Timbal (Pb) Dan Besi (Fe) Dalam Air Laut Di Wilayah Pesisir Pelabuhan Ferry Taipa Kecamatan Palu Utara. Jurnal Akademika Kimia, 1(4), 181-186.

Kadim, M. K., Pasisingi, N., \& Paratama, A. R. (2017). Kajian kualitas perairan Teluk Gorontalo dengan menggunakan metode STORET. Jurnal Ilmu-Ilmu Perairan, Pesisir Dan Perikanan, 6(3), 235-241. https://doi.org/10.13170/depik.6.3.8442

Li, D., Wang, J., Pi, J., Yu, J., \& Zhang, T. (2019). Biotasediment metal accumulation and human health risk assessment of freshwater bivalve Corbicula fluminea in Dongting Lake, China. Environmental Science and Pollution Research, 26(15), 14951-
14961. https://doi.org/10.1007/s11356-01904931-7

Malik, D. S., \& Maurya, P. K. (2015). Heavy metal concentration in water, sediment, and tissues of fish species (Heteropneustis fossilis and Puntius ticto) from Kali River, India. Toxicological and Environmental Chemistry, 96(8), 1195-1206. https://doi.org/10.1080/02772248.2015.10152 96

Mustafa, A., Asaf, R., Kamariah, \& Radiarta, i N. (2021). Konsentrasi Dan Status Mutu Logam Berat Dalam Air Dan Sedimen Di Kawasan Pesisir Kabupaten Kepulauan Sangihe Concentration. Ilmu Dan Teknologi Kelautan Tropis, 12(April), 185-200. https://doi.org/https://doi.org/10.29244/jitkt.v 13i1.35290

PP RI No 22. (2021). Peraturan Pemerintah Nomor 22 Tahun 2021 tentang Pedoman Perlindungan dan Pengelolaan Lingkungan Hidup. Sekretariat Negara Republik Indonesia, 1(078487A), 483. http://www.jdih.setjen.kemendagri.go.id/

Priyanto, N., Dwiyitno, D., \& Ariyani, F. (2008). Kandungan Logam Berat $(\mathrm{Hg}, \mathrm{Pb}, \mathrm{Cd}$, dan $\mathrm{Cu})$ Pada Ikan, Air, dan Sedimen Di Waduk Cirata, Jawa Barat. Jurnal Pascapanen Dan Bioteknologi Kelautan Dan Perikanan, 3(1), 69. https://doi.org/10.15578/jpbkp.v3i1.11

Rachmawatie, Hidayah, Z., \& Abida, I. W. (2009). Analisis Konsentrasi Merkuri (Hg) dan Cadmium (Cd) di Muara Sungai Porong Sebagai Area Buangan Limbah Lumpur Lapindo. Jurnal Kelautan, 2(2), 125-134

Rompas, R. M. (2010). Toksikologi kelautan (Sekretariat Dewan Kelautan Indonesia (ed.)).

Rumahlatu, D. (2012). Konsentrasi Logam Berat Kadmium Pada Air, Sedimen dan Deadema setosum (Echinodermata, Echinoidea) di Perairan Pulau Ambon. ILMU KELAUTAN: Indonesian Journal of Marine Sciences, 16(2), 7885. https://doi.org/10.14710/ik.ijms.16.2.78-85

Sachoemar., dkk, S. I. (2018). Evaluasi Kondisi Lingkungan Perairan Kawasan Pulau Abang, Galang Baru, Batam Berdasarkan Analisa Indeks Storet Dan Similaritas Canbera. Jurnal Rekayasa Lingkungan, 6(1), 81-87. https://doi.org/10.29122/jrl.v6i1.1915

Setiawan, H. (2013). Pencemaran Logam Berat Di Perairan Pesisir Kota Makassar Dan Upaya Penanggulangannya. Info Teknis EBONI, 11(1), 113.

Suryono, C. A. (2016). Polusi LogamBerat Antropogenik (As, $\mathrm{Hg}, \mathrm{Cr}, \mathrm{Pb}, \mathrm{Cu}$ dan $\mathrm{Fe}$ ) pada Pesisir Kecamatan Tugu Kota Semarang Jawa Tengah. Jurnal Kelautan Tropis, 19(1), 37. https://doi.org/10.14710/jkt.v19i1.598

Voica, C., Iordache, A. M., Ionete, R. E., \& Stefanescu, I. (2017). Aspects on the Accumulation of Trace Metals in Various Environmental Matrices (Water, Soil, Plant and Sediments): Case Study on 
Catchment Area of the Somes River, Romania. Water Quality. https://doi.org/10.5772/65700

Walukow, A. F. (2010). Penentuan Status Mutu Air Dengan Metode Storet Didanau Sentanijayapurapropinsi Papua 1 [Determination of Water Quality Status in Sentani Lake of Papua Using STORET Method]. Berita Biologi, 10(3), 277-281.

Yi, Y., Yang, Z., \& Zhang, S. (2011). Ecological risk assessment of heavy metals in sediment and human health risk assessment of heavy metals in fishes in the middle and lower reaches of the Yangtze River basin. Environmental Pollution,
159(10), $2575-2585$. https://doi.org/10.1016/j.envpol.2011.06.011 Yusuf, M., \& Hamzah, B. (2013). Kandungan Merkuri ( Hg ) Dalam Air Laut, Sedimen, Dan Jaringan Ikan Belanak ( Liza melinoptera) DI PERAIRAN TELUK The Mercury ( $\mathrm{Hg}$ ) Content In Sea Water, Sediment And Belanak ( Liza Melinoptera) Tissue In Palu Bay Water. J. Akad. Kim, 2(3), 140-145.

Zhang, G., Pan, Z., Hou, X., Wang, X., \& Li, X. (2015). Distribution and bioaccumulation of heavy metals in food web of Nansi Lake, China. Environmental Earth Sciences, 73(5), 2429-2439. https://doi.org/10.1007/s12665-014-3592-z 